\title{
The reform of the pensions system in Serbia and the proposals of the International Monetary Fund
}

\begin{abstract}
Today in the Republic of Serbia, there is a strong requirement to continue and complete the reform of pensions and disability insurance. This process commenced in 2001 and its content should now be focused on, inter alia: the manner of the indexation of pensions alongside trends in wages; the manner of the indexation of the general point; the increased duration of length of service (i.e. accelerated years of service); the insurance of agricultural workers; and the inclusion of the insurance of military personnel in a single pension system. The reform of the pensions and disability insurance system may not be directed just towards expenditures or to the reduction in the acquired rights of insured people, but it should also include a look at income - that is, issues surrounding better control over the payment of contributions for compulsory pensions or disability insurance; an increase in the number of employees; and the reduction in the grey economy; etc. It must also be recognised that the International Monetary Fund is likely to play an important role in reforming the national pensions system in Serbia.
\end{abstract}

Keywords: pension benefits, points system, personal points, personal coefficient, Swiss formula, indexation of pensions, replacement rate, pay-as-you-go (PAYG)

\section{Introduction}

The system of pensions and disability insurance in the Republic of Serbia, which largely collapsed in the 1990s, is - despite attempts at reform in 2001, 2003 and 2005 - facing serious crises and a difficult financial situation.

During the last two decades, the situation in the area of pensions and disability insurance has experienced negative trends: the number of beneficiaries of pensions and disability insurance is continually growing; while the ratio of the employed (the active population) to the number of pensioners is becoming less and less favourable. In other words, the ratio of the active to the passive part of the population is increasing, while the funds from realistic sources (in the first place from contributions for pensions and disability insurance) intended to finance these rights are insufficient. The consequence is a continuing deficit in the financial operations of the Pensions and Disability Insurance Fund (PDIF), as well as an inconvenient structure of pensions beneficiaries, with an unrealistically high percentage of disability and survivor pensions.

The state's total expenditure in its pensions system - that is, the Pensions and Disability Insurance Fund (Republic of Serbia) - has, during the last years, amounted to about $14 \%$ of GDP. Some $40 \%$ of its total revenues are delivered from the budget of the Republic. The high deficit in the pensions fund (in previous years, it has ranged 
from $5 \%$ to $7 \%$ of GDP) constitutes a significant burden on the entire national economy.

All these issues indicate the necessity to put in place some fundamental reforms of the pensions system of Serbia.

\section{The system of pensions and disability insurance}

\section{The basic characteristics of the pensions and disability insurance system}

The system of compulsory pensions and disability insurance in the Republic of Serbia is based on current financing (pillar I) ${ }^{1}$ and comprises insurance against three basic types of risk:

a) age

b) occurrence of disability

c) the death of beneficiaries.

Insurance covers:

a) employees

b) the self-employed (independent activities)

c) agricultural workers.

Until 2007, compulsory pensions and disability insurance was organised in three separate state funds which, as of 1 January 2008, were administratively integrated. Full financial consolidation is intended to occur in 2011.

Subsequent to 2005, a constituent part of the pensions and disability insurance system of Serbia has also been voluntary pensions insurance in private, funded pension funds (pillar III). ${ }^{2}$

Compulsory pensions and disability insurance in the Republic of Serbia is regulated by the Law on Pensions and Disability Insurance (hereinafter: the Law). ${ }^{3}$ However, the area of pensions and disability insurance is also regulated by the:

- Law on Contributions for Compulsory Social Insurance

- Law on the Payment of Contributions for Pensions and Disability Insurance for individual categories of beneficiaries - the employed

- Law on General Administrative Procedure

- by-laws (books of rules).

Consent regarding all the documents of the Republic Fund for Pensions and Disability Insurance, particularly the financial plan, the report on the financial operations of the Fund and the balance sheet issued on the basis of these laws, is to be given by

1 Current financing - pay as you go - encompasses the financing of pensions out of the contributions paid by present generations of employees and their employers who thus, in the process, acquire the right for their pensions to be financed out of the contributions of future generations.

2 Nine companies manage the property of the ten funds. The total net property of the funds amounts to 6.5 billion dinars (amounting to $0.2 \%$ of GDP compared to the European average of $15 \%$ ). The number of beneficiaries is 163000 , out of which number $40 \%$ are women. The average amount of funds per beneficiary is about 39000 dinars, while the average payment amounts to 3200 dinars (tax relief is 3528 dinars per month).

3 Official Gazette of the Republic of Serbia No. 34/03, 85/05 and 5/09. 
the government of the Republic of Serbia whose documents, including the relevant governmental decisions, are published in the Official Gazette of the Republic of Serbia.

\section{Number and structure of pensioners}

In December 2009, 1.6 million pensioners were covered by state insurance, out of which number 1.3 million (82.58 \%) fall under the category of ex-employees. The category of 'self-employed' accounts for $3.4 \%$, while the category of 'agricultural workers' takes up $14.02 \%$.

Table 1 - Number of pensioners per category of the insured, and type of insurance (December 2009)

\begin{tabular}{|l|c|c|c|c|}
\hline Pensioners & Total & Employed & $\begin{array}{c}\text { Self- } \\
\text { employed }\end{array}$ & $\begin{array}{c}\text { Agricultural } \\
\text { workers }\end{array}$ \\
\hline Total & 1603668 & 1324338 & 54450 & 224880 \\
\hline Old age pension & 893332 & 681908 & 23945 & 187479 \\
\hline Disability pension & 358115 & 329298 & 16218 & 12599 \\
\hline Dependant's pension & 352221 & 313132 & 14287 & 24802 \\
\hline
\end{tabular}

Pensioners from the ex-employees category thus dominate the structure of beneficiaries according to the type of insurance.

Considering the type of pension, the structure of beneficiaries is as follows:

- old age pension: $55.71 \%$

- disability pension: $22.33 \%$

- dependant's pension: $21.96 \%$.

The number of people who have acquired the right to a pension, having a full record of service (only 261000 insured employees have completed more than forty years of service (for men) or 35 (for women)), is not high. Their participation among old age pensioners amounts to $40.4 \%$ and to just $20 \%$ of the total number of pensioners with employment-based insurance.

The ratio of the number of insured people to the number of pensioners is unfavourable. Amongst the category of employees, it amounts to 1.4 employees for each pensioner. ${ }^{4}$

Financial operations of the Pensions and Disability Insurance Fund

In 2008, the expenditure of the Pensions and Disability Insurance Fund (PDIF) amounted to 398 billion dinars, or $14.3 \%$ of GDP.

4 Problems in the functioning of a pensions system that is based on a current financing model occur when this ratio is lower than three employees per pensioner. 
Table 2 - Revenues and expenditures of the Pensions and Disability Insurance Fund in 2008 and the share of GDP (million dinars)

\begin{tabular}{|l|c|}
\hline Revenue (excluding subsidies) & 274338.90 \\
\hline Total expenditure & 398035.80 \\
\hline Pensions expenditure & 333092.70 \\
\hline Deficit regarding coverage of regular expenditure & -123696.90 \\
\hline GDP & 2790900 \\
\hline & \\
\hline Share of GDP & \\
\hline Revenue (excluding subsidies) & $9.8 \%$ \\
\hline Regular expenditure & $14.3 \%$ \\
\hline Pensions expenditure & $11.9 \%$ \\
\hline Deficit for coverage of regular expenditure & $-4.4 \%$ \\
\hline
\end{tabular}

Pensions expenditure in 2008 amounted to 333.1 bn dinars, or $11.9 \%$ of GDP. ${ }^{5}$

The total revenues of the PDIF, excluding subsidies from the budget, amounted to $274.3 \mathrm{bn}$ dinars $(9.8 \%$ of GDP), while the deficit amounted approximately to $123.7 \mathrm{bn}$ dinars $(4.4 \%$ of GDP).

Trends in pension amounts and payment dynamics

The result of the inadequate inflow of funds into the Pensions and Disability Insurance Fund is that pensions are still paid in two parts. However, the payments of pensions have been regular during the last several years.

In December 2009, the average pension for insured employees amounted to 21726 dinars, or $€ 217$ (around $59.1 \%$ of average net wages); for insured self-employed parties, 21291 dinars (57.8\%); and for insured agricultural workers, 8148 (22.2\%).

5 A greater participation of expenditure on pensions in GDP is the case in, for example: Italy, Austria, France, Portugal, the Netherlands, Germany, Sweden and Greece; while a lower participation rate is recorded in Spain, Luxembourg, Ireland and others. 
Table 3 - Amount of average wages and average pensions in the Republic of Serbia in December 2008 and 2009

\begin{tabular}{|l|c|c|c|c|c|c|c|c|}
\hline Year & \multirow{2}{*}{$\begin{array}{c}\text { Average } \\
\text { wages }\end{array}$} & \multirow{2}{*}{$\begin{array}{c}\text { Average net } \\
\text { wages (excl. } \\
\text { taxes and } \\
\end{array}$} & & & \multicolumn{6}{|c|}{ Average pension } \\
\cline { 4 - 9 } & & & \multicolumn{2}{|c|}{ Employed } & \multicolumn{2}{|c|}{ Self-employed } & \multicolumn{2}{c|}{$\begin{array}{c}\text { Agricultural } \\
\text { workers }\end{array}$} \\
\cline { 5 - 9 } & & & Dinar & $\begin{array}{c}\text { \% } \\
\text { contributions) }\end{array}$ & Dinar & $\begin{array}{c}\text { \% } \\
(6: 3)\end{array}$ & Dinar & $\begin{array}{c}\text { \% } \\
(8: 3)\end{array}$ \\
\hline 2008 & 53876 & 38686 & 21713 & 56.1 & 21248 & 54.9 & 8126 & 21.0 \\
\hline 2009 & 51115 & 36789 & 21726 & 59.1 & 21291 & 57.8 & 8148 & 22.2 \\
\hline Index & 94.9 & 95.1 & 100.1 & 105.3 & 100.2 & 105.3 & 100.3 & 105.7 \\
\hline
\end{tabular}

The average pension for insured ex-employees amounted in 2008 to 21713 dinars.

Table 4 - Amount of the average pension in the Republic of Serbia in 2009 and its relationship to average net wages

\begin{tabular}{|l|c|c|c|}
\hline & Employees & Self-employed & $\begin{array}{c}\text { Agricultural } \\
\text { workers }\end{array}$ \\
\hline Old age pension & 25224 & 24669 & 8365 \\
\hline Disability pension & 20045 & 21514 & 8891 \\
\hline Dependant's pension & 15964 & 15503 & 6020 \\
\hline Average pension & 21714 & 21283 & 8139 \\
\hline$\%$ of net wages & 68.4 & 67.1 & 25.6 \\
\hline
\end{tabular}

A pension of 11088 dinars (the lowest amount of pension for insured ex-employees) or lower was, in December 2009, received by $13.93 \%$ of the total number of pensioners, while $59.13 \%$ of them received a pension which was lower than the amount of the average pension.

The uprating of pensions is, in accordance with the most recent amendments to the Law, carried out exclusively in line with the growth in the costs of living. This uprating mechanism is unfavourable for pensioners since it entails a permanent degradation that is, the reduction of purchasing power, which most directly affects pensioners' already low standard of living.

\section{Rights in relation to pensions and disability insurance}

Statutory rights in relation to pensions and disability insurance, in accordance with Article 18 of the Law on Pensions and Disability Insurance, are:

1. in the case of old age - the right to an old age pension

2. in the case of disability - the right to a disability pension 
3. in the case of death:

1. the right to a dependant's pension

2. the right to compensation for funeral expenses

4. in the case of physical injuries caused by an accident at work or by an occupational illness or disease - the right to cash compensation.

\section{Right to an old age pension}

In accordance with Article 4 of the Law on Amendments to the Law on Pensions and Disability Insurance dated 2005, insured people acquire the right to an old age pension:

1. at age 65 (for men) or 60 (women), where there is insurance cover of at least fifteen years

2. after 40 (men) or 35 (women) years of insurance and where the individual is aged at least 53

3. after 45 years of insurance.

The provisions of Article 4 of the Law on Amendments to the Law on Pensions and Disability Insurance are to be applied from 2011, by which point the provisional provisions of Article 69 of the same Law will be applied in full. Specifically, the right to access an old age pension in the period from 2006 to 2010 will be acquired by an insured person:

1. in 2006 and 2007, at age 63 (men) or 58 (women) with an insurance record of at least twenty years

2. in 2008, at age 63 and six months (men) or 58 and six months (women) with at least 19 years of insurance

3. in 2009, at age 64 (men) or 59 (women) with at least eighteen years of insurance

4. in 2010, at age 64 and six months (men) or 59 and six months (women) with at least 17 years of insurance.

We can see that the criterion for old age retirement is being increased over the 2008 to 2011 period (an extension by two years, or by half a year each year).

\section{Indexation of pensions}

In line with Article 80 of the 2003 Law on Pensions and Disability Insurance, pensions used to be uprated:

In the percentage representing the sum of half of the growth percentage or decline in living costs and half of the growth percentage, or decrease, in wages,

- i.e. according to the so-called 'Swiss formula'.

However, Article 21 of the Law on Amendments to the Law on Pensions and Disability Insurance, from 2005, changes this mechanism:

Starting from 1 April and 1 October 2009, pensions shall be uprated based on statistical data, in line with the trends in the living costs on the territory of the Republic in the previous six months. 
However, pursuant to Article 73 of the Amendment Law, and notwithstanding the provisions of the same Law's Article 21, the uprating of pensions was carried out in the period from 2006 to 2008 :

1. from 1 April and 1 October 2006, in accordance with the trends in living costs and in employees' average wages in the previous six months, in a percentage representing $62.5 \%$ of the growth percentage or decline in living costs, and $37.5 \%$ of the growth percentage or decrease in wages

2. from 1 April and 1 October 2007, in a percentage which represents $75 \%$ of the growth percentage or decline in living costs, and $25 \%$ of the growth percentage or decline in living costs

3. from 1 April and 1 October 2008, in a percentage which represents $87.5 \%$ of the change in living costs and $12.5 \%$ of the change in wages.

From 1 January 2009, pensions will be uprated, as already mentioned, based only on the trends in living costs, and they can also be lower than $60 \%$ of the amount of the average wage, net of taxes and contributions, in Serbia. ${ }^{6}$

Basic problems in the functioning of the pensions and disability insurance system

The deterioration in the position of the pensions system in Serbia is being affected particularly negatively by:

a) disadvantageous long-term demographic trends, i.e. the increasing aging of the population. The proportion of younger generations in the entire population is low and on the decline, while the proportion of the elderly is high and on the increase. Serbia counts itself among the five oldest countries in the world, with $16.8 \%$ of the population older than 65 years of age ${ }^{7}$

b) an unfavourable ratio of the number of employed people to the number of pensioners. The ratio of employees per pensioner is, on average, 1.6 and it is even lower, 1.4, in terms of insured employees. The improvement of this ratio lies in the increase of employment and a decrease in the grey economy

6 In accordance with Article 75 of the Law on Amendments to the Law on Pensions and Disability Insurance, the provisions on the extraordinary uprating of pensions benefits, if they amount to less than $60 \%$ of average wages, were applicable for three years or until 2008 inclusive.

7 The percentage of people older than 65 years of age in the total number of inhabitants over the territory of central Serbia is as follows: in 1950, it was $5.5 \% ; 1970,8.8 \% ; 1995,13.8 \%$; and $2000,16.1 \%$. It is estimated that, in 2021 , it will be $21.5 \%$ and, in 2051 , even $31.3 \%$. The median age, which was 38.9 in 2000, will rise, according to estimates, to 44.9 in 2021 and to 52.1 in 2051 (Penev, 2002). 
Figure 1 - System support ratio in the Republic of Serbia

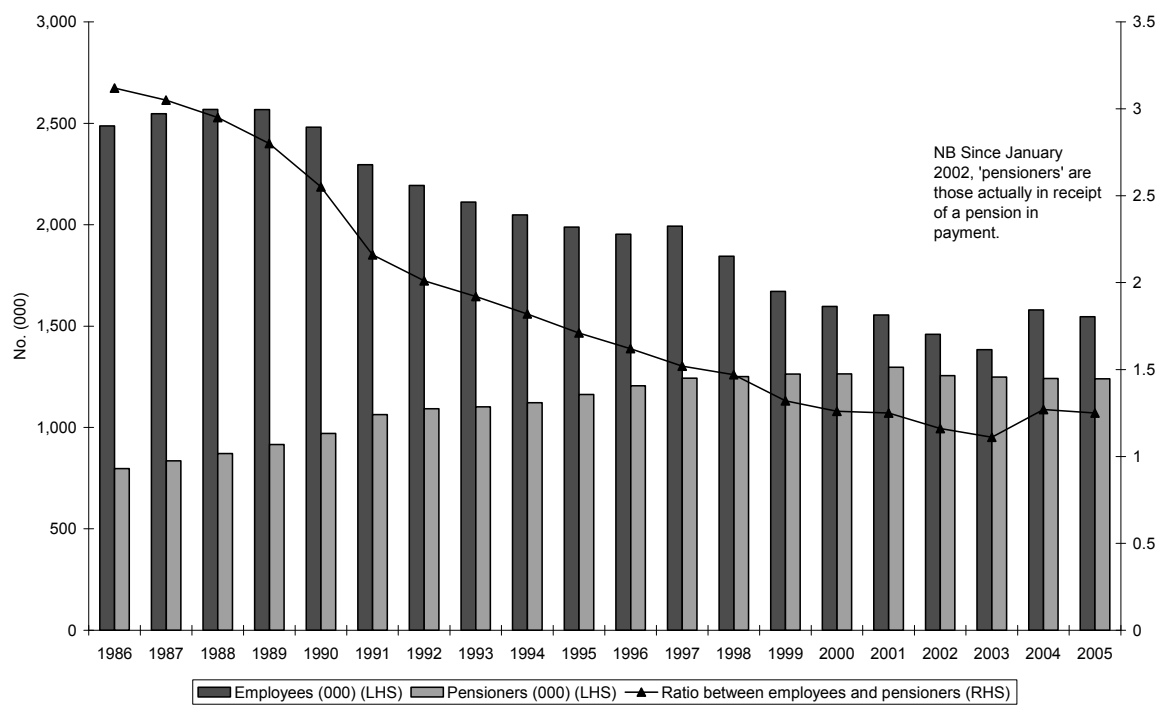

Source: Dragana Petraković (2007) 'Reforma sistema penzijsko-invalidskog osiguranja u Srbiji' Industrija 35(2): 34.

c) a reduction in the number of employees and an increase in the number of those of pensionable age. In the period from 1991, Serbia has been in a process of deindustrialisation. After 2001, with the exception of the food industry, the following industries have been destroyed: the machinery industry; the electro industry; the chemical industry; engines and tractors; the textile industry; and others. In April 2009, the number of employees was, compared to December 2001, lower by 463000

d) evasion of the payment of contributions for pensions insurance. According to data from the Tax Administration of the Ministry of Finance, the total arrears of employee contributions for pensions and disability insurance amounted to, as of 31 March 2009, 58.953bn dinars, out of which 38.31bn dinars pertained to the main arrears and 20.644bn dinars to interest. ${ }^{8}$

e) payment of contributions on the lowest base wage rather than the actual wage

8 On 2 October 2009, the government of the Republic of Serbia adopted a Decision which would enable the linkage of the years of service for employees in respect of whom employers had not paid contributions for pensions and disability insurance. According to the Decision, years of service are to be linked for approximately 80000 workers in respect of the period from 1 January 2004 to 30 June 2009. The previous linkage of years of service was carried out in 2005 for the period from 1991 to 2003. On that occasion, according to the data of the Pensions and Disability Insurance Fund, requests were submitted by some 360000 people while a positive decision was made in favour of 264000 people. 556000 years of service were credited to workers, costing the state $18.6 \mathrm{bn}$ dinars. 
f) the existence of a high share of the informal 'grey', or 'shadow', economy in the economy as a whole. It is estimated that more than 700000 people in Serbia work in the shadow economy

g) relaxed conditions for retirement over a longer period of time (non-selective early retirement and non-selective accelerated retirement plans):

- the share of people on a disability pension is high $(23 \%)$

- the share of pensioners older than 65 years of age among old-age pensioners who were insured as employees amounts to only $62.3 \%$

- amongst those insured as employees, less than $20 \%$ of pensioners have a 'full' service record

- approximately $20 \%$ of pensioners insured as employees are on accelerated retirement plans

h) the redistribution, or investment in other areas, of the revenue surplus in relation to expenditure in the 1970s and 1980s. Instead of using such surpluses to support the pensions fund further, they were used for the construction of various facilities, including health facilities; rehabilitation centres; water facilities; enterprises; mines; and other facilities

i) expenditure on net pensions in 2008 amounted to $11.9 \%$ of GDP (333.1bn dinars), while the total expenditure of the Pensions and Disability Insurance Fund made up $14.3 \%$ of GDP (this includes expenditure on compensation intended for the care and assistance of other people; physical injuries and funeral expenses; the administrative expenses as regards the functioning of the Fund; and expenditure on the health contributions of pensioners). These expenditures, according to 2006 data, are among the highest compared with EU accession countries in transition, but are slightly lower than the EU average and are among the lowest compared with the EU-15

j) the high deficit in the Pensions and Disability Insurance Fund. Nearly $40 \%$ of the necessary funds for the payment of salaries are provided through transfers from the budget of the Republic of Serbia. The deficit regarding the coverage of regular expenditure in 2007 amounted to $3.8 \%$ of GDP; while in 2008, it was $4.4 \%$

k) the low level of pensions compared to wages. In respect of pensioners who had been insured as employees in 2008, their pensions amounted to $59.2 \%$ of average wages. More than $60 \%$ of pensioners receive pensions which are lower than the average

1) pensioners fall within the most vulnerable groups of the population in Serbia, even though the rate of poverty among pensioners is lower than the average for the entire population (according to the Survey on Living Standards in 2007, it amounted to $5.3 \%$ compared to $6.6 \%$ )

m) problems with the economic development of the state. Despite GDP exhibiting large growth rates in the period from 2001 to 2008 (from $4.5 \%$ up to $7.1 \%$ ), the level of GDP in 2007 did not even reach $60 \%$ of the 1989 level

n) problems concerning the pensions insurance of agricultural workers. In 2008, the average old age pension for ex-agricultural workers (7 446 dinars) was lower by $67.1 \%$ than the average old age pension of ex-employees (22 634 dinars) 
o) the hypothetical net replacement rate $^{9}$ for a male with forty years of service and a wage at the average level amounted in 2008 to approximately $73 \%$. This was slightly lower than in EU-15 countries; however, in the long-term, this is being reduced to an unacceptably low level. For example, in 2020, it will amount to only $43 \%$.

Previous outcomes in the reform of pensions and disability insurance in the Republic of Serbia

Significant changes in the system of pensions and disability insurance in Serbia after 2000 were made in 2001, 2003 and 2005.

1. The contents of the legal changes made in 2001 were as follows:

a) the extension of the retirement age (the age was extended by three years, from 55 to 58 years of age for women and from 60 to 63 years of age for men, while the minimum age was shifted from 50 to 53 years)

b) the end of the uprating of pensions in line with wages to quarterly uprating according to the principle of the 'Swiss formula' 10

c) a guarantee of a single level for the minimum wage (20\% of average wages), instead of the establishment of multiple figures depending on the length of years of service

d) the reduction of the contribution rate for pensions and disability insurance from $32 \%$ to $19.6 \%{ }^{11}$ (which resulted in an increase in wages, also inducing a growth in pensions but not a reduction in the grey economy).

2. The applicable Law on Pensions and Disability Insurance was passed in 2003 to establish: a stronger linkage between the size of pensions and the amount of contributions paid; a less complex calculation of pensions; an expansion in the numbers of insured people; a reduction of the liberal elements in the system referring to the acquisition of a right to a pension; the creation of the possibility of voluntary insurance; etc. The following are the most important innovations that occurred with the adoption of this Law in 2003:

a) the introduction of the so-called points system in the calculation of pensions ${ }^{12}$

b) the inclusion of the entire period of service as a basis of the calculation in place of the ten best years

c) the expansion of the numbers of insured people is based on making pensions insurance compulsory (the obligation to pay contributions has been introduced for situations including engagement through author's fees and royalties, short-

9 The hypothetical net replacement rate indicates the relationship between the first pension paid and the last generated wage for a hypothetical worker with full years of service (forty years) with income at the average wage level.

10 In a percentage equal to one-half of the percentage of income growth and one-half of the growth in living costs.

11 Along with the reduction in contribution rates for health insurance and unemployment insurance, the total burden on net wages is reduced from $110 \%$ to $70 \%$. The Law on contributions for compulsory social insurance entailed an increase in this rate from $19.6 \%$ to $22 \%$.

12 The amount of the old age and disability pension is determined by multiplying the personal point to the value of the general point on the date when the right was gained. 
term contracts and work organised through youth and student organisations except for those younger than 27 who are in regular education)

d) introduction of the concept that pensions insurance is paid by all those who are willing to do so, independently of working status (the introduction of voluntary pensions insurance within pillar I)

e) changes in the area of disability pensions (establishment of disability according to the concept of general disability, instead of an incapacity to perform the job; the regular revision of disability pensions; and cancellation of the right to compensation for working shorter working hours and of the right to compensation because of a lower wage level at another corresponding job - II and III category of disability; etc.)

f) changes in the insurance scheme for agricultural workers (instead of compulsory insurance for all household members, the obligation to insure only one member of the household has been established).

3. After the first (2001) and the second (2003), the third wave of changes happened in 2005, via the amendment law to the Law on pensions and disability insurance. The following are the most important innovations arising from the passing of this Law:

a) the gradual extension of the age threshold for retirement by six months until 2011, when the age for women should be 60 and for men 65

b) the gradual uprating of pensions in line only with the increase in living costs from 2009, and only twice instead of four times per year (which, in essence, means a freezing in the living standards of pensioners)

c) extraordinary uprating, in cases where the average pension amounts to less than $60 \%$ of the net average wage in the previous year, to be ended in 2008 which means that, from that year, they may be even lower than $60 \%$

d) increase in the lowest pensions to the level of $25 \%$ of the average wage, with the possibility of extraordinary uprating where they fall below $20 \%$, from 2010

e) administrative consolidation of all three pensions funds as of 2008, and financial consolidation as of 2011.

4. The most recent amendments to the Law on Pensions and Disability Insurance, dated January 2009, retrospectively legalised a $10 \%$ increase in pensions. These had been implemented by a Decree of the Government of the Republic of Serbia from October 2008; there was also the freezing of salaries during 2009, which was continued in 2010 .

Basic trends in the pensions and disability insurance system

\section{Reform objectives}

The basic objectives of the reform of the pensions and disability insurance system in Serbia as these:

a) ensuring the long-term sustainability of the system

b) protection of the living standard of current and future pensioners

c) the efficient collection of contributions to pensions and disability insurance 
d) upgrading of the efficiency of pensions administration

e) strengthening the role of voluntary pensions funds.

\section{Reasons for reform}

The reform of any sector, including the system of pensions and disability insurance, is always initiated for several basic reasons, out of which the following are the most important:

- the irrationality and inefficiency of the system

- an excessive number of beneficiaries

- an imbalance between institutionalised rights and the realistic capacities of the economy

- a discrepancy between proclaimed and exercised rights

- an inadequate level of service quality and, in accordance with this, an upgrading of the level of rights and services.

Specific measures for the implementation of reforms, and for the success of reform activities, depend on the general social, economic and political conditions under which the reforms are conducted. The reform of the pensions and disability system is being conducted under the following conditions:

- political and economic instability (both internal and external)

- decrease in GDP

- unfavourable trends in industrial and agricultural production

- foreign trade deficit

- deficit in the budget and in the social funds

- increase in the rate of unemployment

- the low level of purchasing power and other kinds of revenues

- the unfavourable ratio of the population of working age to that of the passive population, particularly in regard to the number of pensioners

- deterioration of health indicators

- the low standard of living and poverty.

Reforms of both the social sector and the system of pensions and disability insurance are conditioned by:

- the passing and implementation of national and sectoral strategies

- the creation of the conditions for providing higher levels of investment, with a focus on the attraction of foreign direct investment (not based on a cheap labour force) and the growth of production and wages

- a proper functioning of the rule of law and an increase in the efficiency of the state authorities via the provision of social and legal security

- the establishment of labour and social legislations by settling particular labour, legal and social regulations

- the functioning of an independent judiciary

- the development and improvement of social dialogue. 
The contents of the forthcoming reform of the system of pensions and disability insurance should, inter alia, include:

a) defining the age threshold for retirement

b) the modalities of upgrading pensions, i.e. indexation (via the 'Swiss formula' or in some other manner)

c) the mechanisms of upgrading the general point (in line with trends in wages or in some other manner)

d) defining the corresponding level of pension (for instance, the average pension may not be lower than $60 \%$ of the average wage, nor the minimum pension lower than $25 \%)$

e) the collection of contributions for pensions and disability insurance (inter alia, the establishment of a central register of insured people and beneficiaries)

f) the extended duration of insured years (accelerated retirement plans)

g) insurance for agricultural workers

h) inclusion of insurance for military personnel into a unified pensions system

i) the more efficient work of pensions administration (operating at a lower level of expenditure)

j) the strengthening of the third pillar of the system (voluntary pension funds), and other issues.

In the course of the reforms to the pensions and disability system conducted in Serbia thus far, the position has been taken that this system should be based on the following two components:

1. the pay-as-you-go financing of pensions, organised within the state fund (pillar I)

2. the development of voluntary savings for old age in private pensions funds (pillar III).

The notion of including the concept of compulsory saving in private pensions funds along with the above two components of the pensions system - i.e. the so-called pillar II - has been assessed as non-recommendable and rejected for the following reasons:

a) the discouraging experiences of other countries, in particular in the light of the prevailing global economic crises

b) the high transitional costs of the introduction of this pillar

c) the undeveloped financial market in Serbia and the lacking of appropriate administrative capacities for its regulation

d) the necessity for major investments, with uncertain results.

\section{The proposals of the International Monetary Fund}

During negotiations between the government of the Republic of Serbia and the International Monetary Fund, following the second revision of the stand-by arrangement (the value of credit amounting to $€ 2.9 \mathrm{bn}$ ) in November 2009 , the direction of the 
pensions and disability system in the Republic of Serbia has been adjusted in the following ways: ${ }^{13}$

1. by 2015 , the amount of funds disbursed for net pensions shall be reduced to the level of $10 \%$ of GDP

2. pensions in 2010 should be frozen at the level they stood at in 2009 , while the uprating of pensions in 2011 should depend on the recovery of the economy of Serbia

3. maintaining a retirement age of 65 years for men and 60 for women, after they have reached these levels in 2011

4. the gradual extension of the retirement age in respect of a full service record from 53 to 58 for both genders, and in two stages:

- the first stage, taking place in the period from 2011 to 2019, during which the retirement age shall be extended by four months per year to reach a level of 56 years of age

- the second stage, taking place in the period from 2020 to 2023, during which the retirement age shall be extended by six months per year to reach a level of 58 years of age

5. the staged extension from 35 to 38 in the period of the required full years of insurance for women, by four months per year during the period 2011-2019

6. a gradual reduction in the percentage of added years of insurance for women in calculating the pension amount, such that the percentage of added years of insurance shall be gradually decreased from $15 \%$ to $6 \%$ in the period $2011-2019$

7. a gradual extension of the age at which a survivor's pension becomes payable, under which the threshold shall be extended during the period 2012-2020 by six months each year from 55 to 58 years for men and from 50 to 53 years for women

8. a re-assessment of insured years which have extended character (the so-called accelerated retirement plan)

9. the modalities of finding a solution for problems in the pensions insurance system regarding agricultural workers

10. a strengthening of the activities related to the collection of contributions (including the establishment of a central register).

In February 2010, a third revision of the stand-by arrangement with the International Monetary Fund was conducted, with a focus on pensions and disability insurance. On this occasion, consent was achieved in connection with the extension of the retirement age and changes in the exercise of the right to an accelerated retirement plan. However, IMF representatives expressed reservations on the proposal that pensions be uprated in

13 During the second revision of the stand-by arrangement with the IMF, the following was, inter alia, agreed: 1) a wages and pensions freeze in the public sector (up to 1 April 2011 achieving planned savings of 50bn dinars); 2) by 2015, wages should be reduced from an earmarked $10 \%$ of GDP to $8 \%$, while that for pensions should be reduced from the current $13 \%$ to $10 \% ; 3$ ) the dismissal of administrative redundancy at the level of the republic and at the local level; 4) a budget deficit of $4 \%$ in 2010;5) the commencement of the reform of the pensions system (the indexation of pensions in 2011 in line with the increase in living costs, plus any generated increase in GDP over $4 \%$ - leading to different interpretations by some ministers). 
the period from 2011 to October 2012 with the trends in wages. It was decided to conduct fresh discussions on the uprating of pensions during a fourth revision of the stand-by arrangement scheduled for May 2010.

\section{Trade union concerns}

The concerns of the Confederation of Autonomous Trade Unions of Serbia regarding the reform of pensions and disability insurance are these:

1. the efficient control of the collection of contributions for compulsory pensions and disability insurance (via the strict application of the provisions of the Law on Contributions for Compulsory Social Insurance and the Law on Tax Procedure and Administration, and their appropriate amendments)

2. the building up of corresponding control mechanisms to reduce the grey economy and, to that purpose, the passing of appropriate amendments to the applicable legal regulations

3. establish as quickly as possible the central register of contribution payers for compulsory pensions and disability insurance

4. carry out the corresponding amendments to the Law on Pensions and Disability Insurance to avoid consequences for employed people planning to retire where the employer has not made contribution payments for pensions and disability insurance

5. determine ownership of the medical resorts, spas and other fixed property assets intended for the increase of pensioners' living standards, and granting control of this for management purposes to the Republic of Serbia - Pensions and Disability Insurance Fund

6. a return of that portion of funds intended for the use and privatisation of facilities whose construction was financed out of the resources of the Pensions and Disability Insurance Fund of the Republic of Serbia

7. the general point, as one of the elements in the establishment of the pensions level of a beneficiary (personal point $x$ general point), should be uprated in line with the trend in wages (the proposal to uprate this in the manner stipulated for the uprating of pensions is unacceptable)

8. pensions should be uprated twice a year, in accordance with the trend in living costs and average wages on the territory of the Republic of Serbia during the previous six months, at a percentage rate based on $50 \%$ of the growth percentage or decline in living costs and $50 \%$ of the growth percentage or decline in wages - i.e. uprating according to the so-called 'Swiss formula'. (The proposal to uprate pensions 'according to a formula which includes the percentage of the trend in living costs on the territory of the Republic of Serbia in the previous six months and, in case gross domestic product increases by more than $4 \%$, a percentage representing the difference between the generated growth rate of GDP in the previous year and the rate of $4 \%$ ' is unacceptable) $)^{14}$

14 According to the Memorandum on budgetary and fiscal policy for 2010, with projections for 2011 and 2012, GDP growth in 2010 should be $1.5 \%$, rising to $3 \%$ in 2011 and to $5 \%$ in 2012 . 
9. the continued existence of protective provisions with reference to the extraordinary upgrading of pensions where the average pension is less than $60 \%$ of the average wage in the Republic of Serbia

10. the continued existence of protective provisions with reference to the extraordinary upgrading of the lowest pension where it is less than $25 \%$ of the average wage in the Republic of Serbia

11. the period spent in service under special work conditions, which leads to an acquired right to years of service to have an extended duration, to be reduced from the existing ten years to five

12. the renewal of an obligation on the employer to make the payment of contributions for pensions and disability insurance, based on the lowest possible base for employees, by the 30th of each month even where the employer fails to carry out the disbursement of wages (this obligation had been cancelled in 2006).

\section{Draft Law on Amendments to the Law on Pensions and Disability Insurance}

The Council for the Reform of Pensions Insurance, ${ }^{15}$ at its session on 1 July 2009, passed a Conclusion on the establishment of a working group on the reform of the pensions system and the application of systems of voluntary pensions insurance. In January 2010, the Group announced the first version of a Draft Law on Amendments to the Law on Pensions and Disability Insurance, incorporating to the greatest extent the requests that had been made by the IMF.

According to the Draft Law, insured parties should acquire the right to an old age pension:

1. at age 65 (men) or 60 (women), with an insurance record of at least 15 years

2. after 40 (men) or $38^{16}$ (women) years of insurance, and where the individual is at least 58 years old ${ }^{17}$

3. after 45 years of insurance.

Notwithstanding item 2, insured parties should acquire the right to an old age pension:

1. in 2011, after 40 (men) or 35 years and 4 months (women) years of insurance, and aged at least 53 years and 4 months

2. in 2012, after 40 (men) or 35 years and 8 months (women) years of insurance, and aged at least 53 years and 8 months

3. in 2013, after 40 (men) or 36 (women) years of insurance, and aged at least 54

4. in 2014, after 40 (men) or 36 years and 4 months (women) years of insurance, and aged at least 54 years and 4 months

5. in 2015, after 40 (men) or 36 years and 8 months (women) years of insurance, and aged at least 54 years and 8 months of age

6. in 2016, after 40 (men) or 37 (women) years of insurance, and aged at least 55

15 Decision on education of the Council to reform the pension insurance system („Official Gazette of the Republic of Serbia”, No. 134/04.).

16 Deleted 35.

17 Deleted 53. 
7. in 2017, after 40 (men) or 37 years and 4 months (women) years of insurance, and aged at least 55 years and 4 months

8. in 2018, after 40 (men) or 37 years and 8 months (women) years of insurance, and aged at least 55 years and 8 months

9. in 2019, after 40 (men) or 38 (women) years of insurance, and aged at least 56

10. in 2020, after 40 (men) or 38 (women) years of insurance, and aged at least 56 years and 6 months

11. in 2021, after 40 (men) or 38 (women) years of insurance, and aged at least 57

12. in 2022, after 40 (men) or 38 (women) years of insurance, and aged at least 57 years and 6 months.

As regards the indexation of pensions then, according to the first version of the new Draft Law:

Starting in 2011, pensions shall be uprated as of 1 April of the current year according to a formula which includes the percentage of trends in living costs on the territory of the Republic in the previous six months and, if the gross domestic product increases by more than $4 \%$, the percentage representing the difference between the generated growth rate of GDP in the previous year and the rate of $4 \%$, according to the data of the competent Republic Statistical Body.

However, according to the second version of the Draft Law:

Pensions as of 1 April, 1 October and 1 April 2012 shall be uprated in line with the trends in wages on the territory of the Republic in the previous six months.

Pensions as of 1 October 2012 shall be further uprated based on statistical data and in line with trends in living costs on the territory of the Republic in the previous six months.

The disbursement of uprated pensions shall be effective with the disbursement of the April or October pension.

The letter of the Ministry of Labour and Social Policy, dated 26 February 2010 and submitted to the Confederation of Autonomous Trade Unions of Serbia, contains inter alia the following:

... for the provision on the harmonisation of pensions, it was agreed to establish a formula for harmonisation during the forthcoming course of negotiations to be held in May. Specifically, taking into consideration that the International Monetary Fund was moved to harmonise pensions with wages in the public sector, it takes time to obtain a clear picture and to establish the conditions to implement such a solution...

\section{References}

Barr, Nicolas (2006) 'Pensions: Overview of the Issues' Oxford Review of Economic Policy 22(1): 1-14.

Golubović, Velizar (2009) Reforms of pension systems in the states, SFRY successors Budućnost: Novi Sad. 
Holzmann, Robert, Landis MacKellar and Jana Rapanšek (2009) Pension Reform in Southeastern Europe: linking to labor and financial market reform The World Bank: Washington, D.C/Centre of Excellence in Finance, Ljubljana, Slovenia.

International Labour Organisation Central and Eastern European Team (2002) Pension Reform in Central and Eastern Europe, Volume 2, Restructuring of Public Pension Schemes: Case Studies of the Czech Republic and Slovenia ILO: Budapest.

International Labour Organisation Central and Eastern European Team (2002) Pension reform in Central and Eastern Europe, Book 1, Restructuring by privatisation: Analysis of cases in Hungary and Poland ILO: Budapest.

International Labour Organisation (2009) Pension Reform in Serbia from international and regional perspectives Proceedings of the Conference on Pension Reform in Serbia (24-25 September 2009, Belgrade), ILO Sub-regional Office for Central and Eastern Europe: Budapest.

Ivošević, Vanja (2009) Pension Reforms in Europe and their Impact on Women Education International: Belgium.

Matković, Gordana (2009) Challenges of the introduction of a compulsory private pensions system in Serbia Centre for Liberal-Democratic Studies: Belgrade.

Mijatović, Boško (2008) 'Capitalisation of pensions insurance' JP Official Gazette Centre for Liberal-Democratic Studies: Belgrade.

Petraković, Dragana (2007) 'Reforma sistema penzijsko-invalidskog osiguranja u Srbiji’ Industrija 35(2): 29-46.

Serbian Government: Memorandum on budgetary and fiscal policy for 2010 with projections for 2011 and 2012.

Schwarz, Anita M. (2007) Pension System and Labour Costs in Southeastern Europe The World Bank, European and Central Asia Region (http://siteresources.worldbank.org/INTECAREGTOPHEANUT/Resources/Schwartz-Pension_Reform_Western_Balkans.pdf)

Decision on the establishment of the Council for the Reform of the Pensions and Disability Insurance System (Official Gazette of the Republic of Serbia No. 134/04).

Law on Contributions for Compulsory Social Insurance (Official Gazette of the Republic of Serbia No. 84/04, 61/05, 62/06 and 05/09).

Law on Voluntary Pension Funds and Pension Plans (Official Gazette of the Republic of Serbia No. 85/05).

Law on Pensions and Disability Insurance (Official Gazette of the Republic of Serbia No. 34/03, 85/05 and 5/09). 